of East European history at the University of Vienna. The newly established chair was created primarily to strengthen the offerings in the history of the succession states of the monarchy.

The well known Austrian writer Ernst Joseph Görlich celebrated his sixtieth birthday on November 16, 1965. Trained in German, history, and geography at the University of Vienna, he became a teacher at the normal school at Steinberg, in Burgenland, where he remained until 1938. Since the war he has been teaching at the Technologisches Gewerbemuseum in Vienna. Görlich has written a large number of books on a wide variety of topics. Among them are various volumes dealing with important personages in Austrian history and with the history and culture of Austria and the Danubian realm.

On February 15, 1965, the well known writer and journalist Richard Charmatz died in Vienna. Ever since the appearance of his first publication, Der demokratisch-nationale Bundesstaat österreich, in 1904, Charmatz had concerned himself almost exclusively with problems of Austrian history. Fritz Fellner, of the University of Salzburg, paid tribute to Charmatz in a lengthy obituary published in the March, 1965, issue of Forum (pp. 113-114). In it he called Charmatz "the historian of liberal Austria."

\title{
DOCUMENTS COLLECTIONS
}

During the summer of 1964 a collection of documents that is very important for contemporary Austrian history was found in Black Lake, in the Bohemian Forest in Czechoslovakia: the secret files of the Historical Commission of Reichsführer SS. They are entitled "The Rebellion of the Austrian National-Socialists in July, 1934." The Czechoslovak Academy of Sciences in Prague has made photostatic copies of this material for the Dokumentationsarchiv des österreichischen Widerstandes and the Osterreichisches Institut für Zeitgeschichte in Vienna. These documents were published by Europa Verlag in 1965, together with an introduction by Ludwig Jedlicka and Herbert Steiner.

The Documentation Archive of the Austrian Resistance 
Movement is collecting all documents and testimony about Nazi persecutions and the Austrian resistance movement in Austria from 1938 to 1945 . The Archive is especially searching for documents, photographs, and the testimony of eyewitnesses. It is also collecting material on the resistance movement among Austrian exiles. Anyone having such source materials is invited to get in touch with the Documentationsarchiv des Osterreichischen Widerstandes, Wien, Postamt 37, Postfach 63.

\section{SPECIAL CONFERENCES AND EXHIBITS}

The 1964 annual meeting of the Forschungsinstitut für den Donauraum was held at Linz from October 2 to 5,1964 . Most of the papers dealt with the general problem of "The Economy of the Danubian States and the West." They were published in Jahrgang 1965, No. 1-2, of Der Donauraum.

The twelfth meeting of the historical section of the Institut für Osterreichkunde was held at St. Pölten, Lower Austria, from April 11-15, 1965. In view of the six hundredth anniversary of the Vienna University, the general topic of "Rudolph IV and his Times" was chosen as the main theme for discussion. The principal address was given by Alphons Lhotsky, of the Institut für österreichische Geschichtsforschung, in Vienna. It was entitled "Rudolph IV. Problems involved in interpreting his Personality."

The Südosteuropa Society, of Munich, held its annual meeting in Bonn from May 3-5, 1965. The general theme of the conference was "Current German-Southeastern Europe Economic Problems."

A conference dealing with problems concerning the history of the Sudeten German minorities in Czechoslovakia was organized by the Collegium Carolinum. It met in Stuttgart on June 3-4, 1965.

The Arbeitsgemeinschaft für die Geschichte der Arbeiterbewegung in Osterreich organized an "International Scientific Conference on the History of the Labor Movement" which was held at Linz, Upper Austria, between August 18 and 25, 1965. At this meeting Rudolf Neck read a paper on "Linz in 